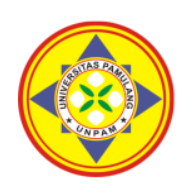

\title{
PENGARUH KOMPENSASI DAN DISIPLIN KERJA TERHADAP KINERJA KARYAWAN PADA CV. BOJONG JAYA KABUPATEN TANGERANG
}

\author{
${ }^{1}$ Viktor Tamba, ${ }^{2 *}$ Bachtiar Arifudin Husain \\ Universitas Pamulang, Tangerang Selatan, Banten, Indonesia \\ *dosen01773@unpam.ac.id
}

\begin{abstract}
Abstrak
Penelitian ini bertujuan untuk mengetahui pengaruh kompensasi terhadap kinerja karyawan pada CV Bojong Jaya Kabupaten Tangerang, untuk mengetahui pengaruh disiplin kerja terhadap kinerja karyawan pada CV Bojong Jaya Kabupaten Tangerang. Metode penelitian ini menggunakan metode kuantitatif dengan pendekatan deskriptif. Metode pengumpulan data yang digunakan adalah angket kuesioner. Analisis data yang digunakan yaitu uji validitas, uji reliabilitas, uji normalitas, uji multikolinearitas, uji heterokedastisitas, koefisien korelasi ,regresi linier sederhana, regresi linier berganda, koefisien determinasi, dan uji hipotesis. engujian hipotesis secara parsial variabel Kompensasi $(\mathrm{X} 1)$ nilai $\mathrm{t} \_\{\text {hitung\} untuk variabel kompensasi }(\mathrm{X} 1) \text { terhadap kinerja }(\mathrm{Y}) \text { adalahh sebesar }$ 6,697, sedangkan nilai $t_{-}\{$tabel\} untuk $\mathrm{N}=42$ adalah sebesar 2,021 jadi 6,697 > 2,021 dapat di simpulkan bahwa secara parsial variabel kompensasi mempunyai pengaruh yang signifikan terhadap kinerja kariyawan. nilai t_\{hitung \\}untuk variabel disiplin kerja (X2) terhadap kinerja kariyawan $(\mathrm{Y})$ adalah sebesar 7,791, sedangkan nilai t_\{tabel \\}untuk $\mathrm{N}=42$ adalah sebesar 2,021, jadi 7,791 > 2,021dapat di simpulkan bahwa secara parsial variabel disiplin kerja mempunyai pengaruh yang signifikan terhadap kinerja kariyawan. Variabel kompensasi (X1), dan disiplin kerja (X2) secara simultan terhadap kinerja kariyawan $(\mathrm{Y})$ positif dan signifikan karena nilai f_\{hitung $\backslash\}>\backslash$ dari nilai $\mathrm{f}_{-}\{$tabel $\backslash\}$ yaitu 34,197 > 2,85 dan nilai signifikan $<0,05$ sehingga Ho ditolak dan Ha diterima. Maka dapat diakatakan bahwa disiplin kerja dan kompensasi berpengaruh signifikan secara simultan terhadap kinerja karyawan.Koefisien determinasi diperoleh nilai $\mathrm{R}$ Square sebesar 0,618, artinya variabel kompensasi dan disiplin kerja secara bersama-sama memiliki kontribusi pengaruh sebesar $61,8 \%$ terhadap kinerja karyawan. Sedangkan sisanya sebesar 39,2\% dipengaruhi oleh faktor lain yang tidak diteliti dalam penelitian ini.

Kata Kunci: Kompensasi, Disiplin Kerja, Kinerja Karyawan
\end{abstract}

\begin{abstract}
This study aims to determine the effect of compensation on employee performance at $C V$ Bojong Jaya Tangerang Regency, to determine the effect of work discipline on employee performance at CV Bojong Jaya Tangerang Regency. This research method uses quantitative methods with a descriptive approach. The data collection method used was a questionnaire questionnaire. The data analysis used was validity test, reliability test, normality test, multicollinearity test, heteroscedasticity test, correlation coefficient, simple linear regression, multiple linear regression, determination coefficient, and hypothesis testing. The partial hypothesis testing of the Compensation variable (X1), the value of t count for the compensation variable (X1) on performance ( $Y$ ) is $h$ of 6.697 , while the $t$-table value for $N=42$ is 2.021 so $6.697>2.021$ can be concluded that partially the compensation variable has an effect. significant impact on the performance of the Kariyawan. the t_value (count) for the work discipline variable (X2) on the career performance $(Y)$ is 7,791, while the $t_{-}$(table) value for $N=42$ is 2,021, so 7,791> 2,021 can be concluded that partially the work discipline variable has significant influence on the Kariyawan performance. The compensation variable (X1) and work discipline (X2) simultaneously on the career performance $(Y)$ are positive and significant because the value of $f_{-}($count $)>$from the value of $f_{-}$(table) is 34.197> 2.85 and the significant value is $<0.05$, so that Ho was rejected and Ha accepted. So it can be said that work discipline and compensation simultaneously have a significant effect on employee performance. The coefficient of determination is obtained by the $R$ Square value of 0.618 , meaning that the compensation and work discipline variables together have an influence contribution of $61.8 \%$ on employee performance. While the remaining $39.2 \%$ is influenced by other factors not examined in this study.
\end{abstract}

Keywords: Compensation, Work Discipline, Employee Performance. 


\section{PENDAHULUAN}

Setiap perusahaan membutuhkan sumber daya manusia untuk mencapai tujuan perusahaan. Keberhasilan pencapaian tujuan ditentukan oleh sumber daya manusia yang berkualitas atau sebaliknya. Di era perkembangan teknologi yang semakin pesat, banyak memberikan dampak positif maupun negatif terhadap perkembangan kemajuan perusahaan. Saat ini banyak kita temui perusahaan-perusahaan yang saling bersaing untuk meningkatkan kualitas kerja serta untuk menjadi yang terbaik di Indonesia. Cv.Bojong Jaya merupakan perusahaan yang bergerak di bidang distributor utama bahan bangunan berupa: semen, bondek, spandek, pasir, batu, grand hebel dan lain-lain. Perusahaan ini bukan hanya distributor saja, namun juga dapat memproduksi batu bata merah dan grand hebel yang berkualitas baik dan terjangkau untuk masyarakat banyak. Sebagai distributor yang tumbuh dan berkembang dan dapat terpercaya bertumpu pada potensi memasok barang keperluan pelanggan. Upaya ini harus di imbangi dengan pengelolaan sumber daya manusia sebagai ujung tombak dalam pelayanan konsumen.

Cv.Bojong Jaya berlokasi di Jln. Raya Bojong Legok no.53, Kabupaten Tangerang. Perusahaan ini di dirikan pada tahun 2010, oleh bapak Hendy. Perusahaan ini sudah berjalan cukup lama, namun pada tahun 2015 perusahaan ini di ambil alih oleh anak pertama dari bapak Hendy dan di teruskan oleh anaknya sendiri atas nama bapak Excel dan sampai saat ini perusahaan tersebut masih di kelolah oleh bapak Excel. Kompensasi merupakan sesuatu yang di pertimbangkan sebagai suatu yang sebanding. Kompensasi adalah segala sesuatu yang di terima karyawan sebagai balas jasa kerja mereka. Dengan memberikan kompensasi organisasi dapat meningkatkan kinerja, motivasi dan kepuasan kerja kariawan. Kesalahan dalam menerapkan sistem penghargaan akan menimbulkan akibat demotivasi dan tidak ada nya kepuasan kerja di kalangan pekerja. Apabila hal tersebut terjadi, dapat menyebabkan turunya kinerja baik pekerja maupun organisasi. Dalam kenyataanya setiap organisasi menerapkan sistem kompensasi secara fleksibel dan bebas sesuai dengan kondisi masing-masing. Sistem mana yang di rasa tepat untuk memberikan kompensasi kepada pekerja dengan harapan dapat meningkatkan kinerja dan menumbuhkan kepuasan kerja. Salah satu kompensasi pada perusahaan CV. Bojong Jaya Kabupaten Tangerang.

Gaji yang tidak sama antara karyawan akan menimbulkan perselisihan dan semangat kerja akan rendah dan juga timbulnya kurang motivasi karyawan tersebut. Di samping itu perusahaan juga sering melakukan penggajian tidak tepat waktu, dimana perusahaan mengundur tiga hari bahkan sampai lebih dari tiga hari. Hal ini juga meningkatkan keluhan-keluhan kariawan, penyebab mogok kerja, dan kurangnya disiplin dalam bekerja. Salah satu indikator penurunan semangat kerja adalah menurunya disiplin karyawan sehingga mengakibatkan efektivitas perusahaan menurun. Tingkat kedisiplinan yang rendah pada tahap selanjutnya akan berakibat pada biaya ekonomi tinggi yaitu terciptanya praktek-praktek kerja yang tidak efektif. penulis dapat menyimpulkan bahwa disiplin kerja adalah sejumlah aturan yang harus dipatuhi oleh para pekerja guna mencapai tujuan perusahaan.

Manajemen kinerja merupakan manajemen yang menciptakan hubungan dan memastikan komunikasi yang efektif. Manajemen kinerja memfokuskan pada apa yang di perlukan organisasi, manejer dan pekerja untuk berhasil. Manajemen kinerja adalah tentang bagaimana kinereja di kelola untuk memperoleh sukses. Kinerja berasal dari pengertian performance. Ada pula yang memberikan pengertian performance sebagai hasil kerja atau prestasi kerja. Namun sebenarnya kinerja mempunyai makna yang lebih luas, bukan hanya hasil kerja, tapi termasuk bagaimana proses pekerja berlangsung. Faktor turunya kinerja karyawan disebabkan karena kurangnya disiplin karyawan, sehingga menyebabkan menurunya proses tingkat penjualan ataupun target dari perusahaan tersebut. Sebagai bahan perbandingan antara menurunya 
disiplin dan menurunya kinerja karyawan, penulis menambahkan tabel penjualan pada perusahaan Cv. Bojong Jaya Kabupaten Tangerang.

Berdasarkan hasil uraian diatas, dapat di lihat bahwa tidak stabilnya target pencapaian perusahaan yang di sebabkan kinerja karyawan yang tidak efektif. maka penulis Tertarik untuk melakukan penelitian pada perusahaan $\mathrm{Cv}$ Bojong Jaya dengan Judul: Pengaruh Kompensasi dan Disiplin Kerja Terhadap Kinerja Karyawan Cv. Bojong Jaya Kabupaten Tangerang.

\section{TINJAUAN PUSTAKA}

\section{Kompensasi}

Pada dasarnya manusia bekerja juga ingin memperoleh uang untuk memenuhi kebutuhan hidupnya. Untuk itulah seorang karyawan mulai menghargai kerja keras dan semakin menunjukkan loyalitas terhadap perusahaan. Perusahaan memberikan penghargaan kepada karyawan atas prestasi yang di raih dengan bentuk kompensasi. Menurut William B. Warther dan Davis dalam Hasibuan (2105:119),"Compensation is what employee receive in exchange of their work, whether hourly wages or periodic salaries, the personnel dapartement usually designs and administers employee compensation". (Kompensasi adalah apa yang seorang pekerja terima sebagai balasan dari pekerjaan yang di berikanya, baik upah perjam ataupun gaji periodik di desain dan di kelolah oleh bagian personalia).

Filippo dalam Hasibuan (2015: 119), "Wages is defined as the adequate and equitable renumeration of personnel for their constribution to organizational objectives". ( upah di defenisiskan sebagai balas jasa yang adil dan layak di berikan kepada pekerja atas jasa-jasanya dalam mencapai tujuan organisasi).

\section{Menurut Dessler (2015:7)} mendefenisikan bahwa Kompensasi karyawan adalah semua bentuk pembayaran atau hadiah yang di berikan pada karyawan dari pekerjaan mereka. Berdasarkan defenisi diatas, secara ringkas penulis mendefenisiskan bahwa kompensasi adalah segala sesuatu yang di terima karyawan atas pekerjaanya berupa uang, tunjangan maupun bonus sehingga dapat memenuhi kebutuhan nya baik secara langsung maupun tidak langsung.

\section{Disiplin Kerja}

Menurut Singodimedjo (dalam Edy Sutrisno, 2017:86), disiplin adalah sikap kesediaan dan kerelaan seorang untuk mematuhi dan menaati normanorma peraturan yang berlaku di sekitarnya. Menurut Terry (dalam Edy Sutrisno 2017:87) disiplin merupakan alat penggerak pegawai. Disiplin yang baik akan sangat mempengaruhi proses berelangsungnya pencapainyan tujuan perusahaan.

Menurut Latainer (2017:87) mengartikan disiplin sebagai kekuatan yang berkembang dalam tubuh pegawai dan menyebabkan pegawai dapat menyesuaikan diri dengan sukarela pada keputusan, peratuaran, dan nilainilai tinggi dari pekerjaan dan perilaku. Sedangkan menurut Handoko (2014:208), disiplin adalah kegiatan manajemen untuk menjalankan standarstandar organisasional. Dari pendapat ini standar peraturan perusahaan akan ternilai dengan tingkat disiplin karyawan, apakah karyawan sudah menjalankan standard dan prosedur yang berlaku atau tidak, serta keefektifan standar perusahaan dalam menindak lanjuti hasil temuan disiplin kerja karyawan.

Dari beberapa teori menurut para ahli diatas maka, penulis mendefenisikan disiplin adalah bentuk kesediaan dan sikap hormat, taat peraturan dalam menjalankan suatu standar organisasional untuk tercapainya tujuan perusahaan yang efektif dan efesien. 


\section{Kinerja}

Kinerja merupakan sesuatu yang paling terpenting bagi perusahaan. Baik buruknya kinerja karyawan sangat berpengaruh pada proses pencapaian tujuan perusahaan, karena tanpan kinerja yang baik perusahaan tidak akan bangkit atau semakin maju. Kinerja karyawan dapat di lihat dari seberapa banyak karyawan memberikan tenaga, pikiran atau kontribusi kepada perusahaan. Menurut Sutrisno (2014:150), mendefenisikan bahwa kinerja adalah hasil upaya yang di tentukan oleh kemampuan krakteristik pribadinya serta prestasinya terhadap perananya dalam pekerjaan itu.

Menurut Mangkunegara (2017:9), mengemukakan bahwa kinerja karyawan adalah (prestasi kerja) hasil kerja secara kualitas dan kuantitas yang di capai seorang karyawan dalam melaksanakan tugasnya sesuai dengan tanggung jawab yang di berikan kepadanya.

Menurut Benardin dan Russel dalam Priansa (2018:270), menyatakan bahwa kinerja merupakan hasil yang di produksi oleh fungsi kegiatan tertentu atau kegiatankegiatan pada pekerjaan terntentu selama periode waktu tertentu, yang memperlihatkan kualitas dan kuantitas dari pekerjaan tersebut. Menurut Mathis dan Jackson dalam Priansa (2018:269), menyatakan bahwa pada dasarnya kinerja adalah apa yang di lakukan dan tidak di lakukan oleh pegawai dalam mengemban pekerjaanya. Menurut Simamora (2014:339) menyatakan bahwa kinerja (performance) mengacu pada kadar pencapaian tugas-tugas yang membentuk sebua pekerjaan karyawan. Kinerja merefleksikan seberapa baik karyawan memenuhi persyaratan sebuah pekerjaan. Dari beberapa landasan teori yang di kemukakan para ahli diatas maka penulis dapat menyimpulkan bahwa kinerja adalah hasil dari pekerjaan seseorang atau sekelompok orang yang melaksanakan sesuatu kegiatan baik secara kualitas maupun kuantitas serta bertanggung jawab penuh atas pekerjaanya.

\section{METODE}

Untuk memperoleh data dalam penelitian ini, penulis memilih tempat penelitian di lakukan pada CV. Bojong Jaya Kabupaten Tangerang, yang beralamat di jln.Raya Bojong No.53 Legok, Tangerang. Sifat penelitian yang di gunakan dalam skripsi ini adalah bersifat kuantitatif, yaitu hasil penelitian yang kemudian di olah dan di analisis untuk mengambil kesimpulanya, artinya penelitian yang di lakukan adalah penelitian yang menekan analisanya pada data-data angka, dengan metode ini akan di ketahui hubungan yang signifikan antara variable yang di teliti, sehingga menghasilkan kesimpulan yang akan memperjelas gambaran mengenai objek yang di teliti.

Sesuai dengan penelitian yang penulis ambil, yaitu pengaruh kompensasi dan disiplin kerja terhadap kinerja karyawan pada CV. Bojong Jaya Kabupaten Tangerang, maka populasi yang penulis ambil dalam penelitian ini adalah seluruh karyawan CV. Bojong Jaya Kabupaten Tangerang, yang sampai saat ini masih aktif bekerja di CV. Bojong Jaya Kabupaten Tangerang dengan jumlah keseluruhan 42 (empat puluh dua ) orang. Supaya data yang di ambil representatif atau mewakili, maka besarnya sampel yang akan di ambil harus di tentukan dan harus mencerminkan karakteristik populasi. Sampel merupakan bagian dari jumlah dan karakteristik yang di miliki oleh populasi, penelitian tidak mungkin mempelajari semua yang ada pada populasi, oleh karena itu sampel pada karyawan CV Bojong Jaya Kabupaten Tangerang, berjumlah 42 orang.

\section{HASIL DAN PEMBAHASAN}

Pada penelitian ini, peneliti berusaha untuk memperoleh gambaran penuh pengaruh kompensasi dan disiplin kerja terhadap kinerja kariyawan pada cv. Bojong Jaya Kabupaten Tangerang. Berikut ini adalah pembahasan dari pengelolaan data yang telah di jelaskan sebelum nya:

1. Pengaruh Kompensasi (X1) terhadap Kinerja Kariyawan (Y) 
2. Berdasarkan uji statistik di peroleh nilai $t_{\text {hitung }}$ sebesar 6,697 sedangkan nilai $t_{\text {tabel }}$ untuk $\mathrm{N}=42$ adalah sebesar 2,021. Jadi 6,697> 2,021 dan di simpulkan secara parsial variabel kompensasi mempunyai pengaruh signifikan terhadap kinerja kariyawan.

3. Pengaruh Disiplin Kerja (X2) terhadap Kinerja Karyawan $(Y)$

4. Berdasarkan uji statistic di peroleh nilai $t_{\text {hitung }}$ sebesar 7,791 sedangkan nilai $t_{\text {tabel }}$ untuk $\mathrm{N}=42$ sebesar 2,021. Jadi $7,791>2,021$. Dapat di simpulkan bahawa secara parsial variabel disiplin kerja mempunyai pengaruh signifikan terhadap kinerja karyawan.

5. Pengaruh Kompensasi dan Disiplin Kerja secara simultan terhadap Kinerja Karyawan.

Berdasarkan pada nilai $F$ di peroleh $f_{\text {hitung }}$ 34,197 dapat di jelaskan bahwa pengaruh antara variabel kompensasi dan disiplin kerja secara simultan terhadap kinerja kariyawan positif dan signifikan karena nilai $f_{\text {hitung }}$ $>$ nilai $f_{\text {tabel }}$ yaitu 34,197 > 2,85 dan nilai signifikan $<0,05$ sehhingga Ho di tolak dan Ha di terima. Pada model regresi linear berganda di peroleh persamaan $Y$ $=13,182+X 1=265+X 2=455$ di mana nilai konstanta intersep sebesar 13,182 merupakan nilai konstanta (a). Nilai dari koefisien regresi variabel kompensasi terhadap kinerja karyawan adalah sebesar 0,265 . hal ini di atrikan jika variabel kompensasi naik $1 \%$ maka akan meningkat variabel kinerja sebesar 0,265 dengan asumsi variabel kompensasi dan disiplin kerja di anggap konstan. Nilai dari koefisien regresi variabel disiplin kerja terhadap kinerja adalah sebesar 455 hal ini dapat di artikan bahwa jika variabel disiplin kerja meningkat 1 maka akan meningkatkan variabel kinerja sebesar 455 dengan asumsi variabel kompensasi dianggap konstan.

Pada nilai koefisien determinasi di peroleh nilai R sebesar 0,798 atau 79,8 \% yang berarti korelasi kompensasi dan disiplin kerja terhadap kinerja kariyawan pada kategori sangat kuat
$(0,798$ - 1,0) dengan nilai koefisien determinasi adjusted $R^{2}$ (adjusted $R$ square) sebesar 0,618. Hal ini menunjukkan bahwa sebesar 61,8\% kompensasi dan disiplin kerja secara simultan terhadap kinerja karyawan atau bersama-sama mempengaruhi kinerja, sedangkan sisanya sebesar 39,2 \% di pengaruhi oleh faktor lain nya yang tidak di teliti dalam penelitian ini.

\section{PENUTUP \\ Kesimpulan}

Berdasarkan hasil penelitian dan pembahasan hasil serta berpedoman pada tujuan penelitian,seperti yang di paparkan pada bab sebelumnya, maka dapat di tarik kesimpulan penelitian ini sebagai berikut:

1. Berdasarkan hasil uji regresi berganda secara parsial, hasil uji $t$ menunjukkan bahwa variabel kompensasi (X1) berpengaruh signifikan terhadap kinerja kariyawan (Y) dari uji statistic di peroleh nilai $\mathrm{f} \_\{\text {hitung\} sebesar 6,697 sedangkan }$ nilai t_\{tabel $\backslash\}$ untuk $\mathrm{N}=42$ adalah sebesar 2,021. Jadi 6,697>2,021.

2. Berdasarkan hasil uji regresi berganda secara parsial, hasil uji $t$ menunjukkan bahwa variabel disiplin kerja (X2) berpengaruh signifikan terhadap kinerja kariyawan (Y). Berdasarkan uji statistic di peroleh nilai t_\{hitung \\}sebesar 7,791 sedangkan nilai t_\{tabel $\backslash$ \} untuk $\mathrm{N}=42$ sebesar 2,021. Jadi 7,791 >2,021.

3. Berdasarkan hasil uji regresi berganda secara simultan, hasil uji F menunjukkan bahwa variabel kompensasi ((X1) dan disiplin kerja (X2) berpengaruh signifikan terhadap kinerja kariyawan (Y) dari uji $F$ di peroleh $f_{-}\{$hitung\} 34,197 dapat di jelaskan bahwa pengaruh antara variabel kompensasi dan disiplin kerja secara simultan terhadap kinerja kariyawan positif dan signifikan karena nilai f_\{hitung\} > nilai f_\{tabel\} yaitu $34,197>2,85$ dan nilai signifikan $<0,05$ sehhingga Ho di tolak dan Ha di terima.

\section{Saran}

Berdasarkan hasil penelitian pembahasan dan kesimpulan di atas, 
penulis dapat memberikan saran yang berhubungan dengan kompensasi dan disiplin kerja terhadap kinerja kariyawan, antara lain sebagai berikut:

1. Berdasarkan variabel Kompensasi (X1) peneliti mendapatakan jawaban objek penelitian berdasarkan variabel kompensasi yaitu dengan nilai rata-rata paling terendah sejumlah 2,78. Pada indikator nomor 2, dimana "Besarnya upah yang saya terima sesuai dengan hasil upaya yang saya berikan kepada karyawan". Maka dari hasil penelitian tersebut, peneliti mengharapkan upah karyawan di naikkan sesuai dengan jumlah UMR Kabupaten tangerang.

2. Pada variabel disiplin kerja (X1) peneliti mendapatkan kesimpulan bahwa balas jasa yang di terima karyawan belum sesuai dengan yang di harpakan karyawan. Pada tabel jawaban objek penelitian berdasarkan variabel disiplin kerja di peroleh nilai rata-rata paling terkecil adalah senilai 2,76. Pada indikator nomor 3 balas jasa, dimana "Balas jasa yang saya terima dari perusahaan sesuai dengan hasil kerja keras saya".Maka dari hasil penelitian tersebut peneliti mengharapkan balas jasa yang di terima karyawan sesuai dengan kinerja yang di harapkan dan layak terhadap karyawan suapaya seluruh karyawan dapat bekerja sesuai dengan aturan dan peraturan.

3. Pada variabel kinerja karyawan (Y), Setiap karyawan harus mampu mengusai atau memiliki keterampilan dalam perusahaan. Jawaban objek penelitian berdasarkan variabel kinerja karyawan di peroleh nilai rata-rata paling terkecil yaitu sebesar 2,21. Pada indikator Kinerja karyawan mengenai alat atau sarana nomor 4, dimana "Sarana yang di sediakan perusahaan sesuai dengan kebutuhan karyawan". Maka dari hasil tersebut di harapkan karyawan meningkatkan kinerja yang baik, dan perusahaan juga harus menyediakan sarana yang lebih baik lagi demi kenyamanan karyawan.

4. Bagi CV. Bojong Jaya Kabupaten
Tangerang, hendaknya meningkatkan kinerja perusahaan tiap tahun nya agar mampu bersaing dalam memperoleh kepercayaan dari investor sehingga memudahkan untuk memperoleh modal dari luar perusahaan.

5. Bagi peneliti selanjutnya, hasil penelitian ini bisa di gunakan sebagai bahan perbandingan dan referensi untuk penelitian, dan sebagai bahan pertimbangan untuk lebih mempe mengkaji lebih banyak sumber maupun referensi yang terkait dengan kompensasi, disiplin kerja dan kinerja karyawan

\section{DAFTAR PUSTAKA}

A.A. Anwar Prabu Mangkunegara, "Manajemen Sumber Daya Manusia Perusahaan", PT Remaja Rosdakarya, Bndung, 2017.

Abdullah, M.Ma'ruf, "Manajemen Dan Evaluasi Kinerja Karyawan", Aswaja Pressindo, Yogyakarta, 2014.

Dessler, gary, "Manajemen sumber daya manusia Human Resource

Management", Jakarta, salemba Empat, 2015.

Filippo, Edwin B. 1984, "Personnel Management", Sixth Edition, (dalam hasibuan. Malayu S.P. 2015) New york: Mc. Graw-hill book company.

Ghozali, Imam "Aplikasi Analisis Multivariate dengan Program SPSS",Semarang, Badan Penerbit Universitas Diponegoro,2016.

Hasibuan, Malayu S.P, "Manajemen Sumber Daya Manusia", Edisi revisi, PT Bumi Aksara, Jakarta, 2017.

Hermawati, R., Sugiyarti, L., Handayani, R., Sunarsi, D., Alfiah, S., \& Maddinsyah, A. (2020). The Effect of Trilogy Leadership Style and Organization Culture on School Performance: Evidence form Indonesian Senior High School. PalArch's Journal of Archaeology of Egypt/Egyptology, 17(6), 8512-8537.

Husain, B. A. (2020). Pengaruh Kompensasi Terhadap Disiplin Kerja Karyawan Pada PT. Strategic Pestcontrol Tebet 
Jakarta Selatan. JENIUS (Jurnal Ilmiah Manajemen Sumber Daya Manusia), 3(3), 277-285.

Kasmir, "Manajemen Sumber Daya Manusia ( Teori dan Praktik)", PT.Raja Grafindo

Lewenussa, R., \& Rawi, R. D. P. (2020). Discriminant Study with Classification of Underdeveloped and Developing City Districts in West Papua Province. Ekuilibrium: Jurnal Ilmiah Bidang Ilmu Ekonomi, 15(2), 103117.

Marihot, Tua Efendi. "Manajemen Sumber Daya Manusia",Grasindo, Jakarta, 2013.

Marwansyah, "Manajemen Sumber Daya Manusia" edisi revisi II, Alfabeta, Bandung, 2016

Mutis. Thoby. Dr. Prof, "Pengembangan Koperasi", PT Gramedia, Jakarta, 1992, Mangkunegara, 2014.

Nurjaya, N., Affandi, A., Ilham, D., Jasmani, J., \& Sunarsi, D. (2021). Pengaruh Kompetensi Sumber Daya Manusia Dan Kemampuan Pemanfaatan Teknologi Terhadap Kinerja Aparatur Desa Pada Kantor Kepala Desa Di Kabupaten Gunungkidul, Yogyakarta. JENIUS (Jurnal Ilmiah Manajemen Sumber Daya Manusia), 4(3), 332-346.

Pawar, A., Sudan, K., Satini, S., \& Sunarsi, D. (2020). Organizational Servant Leadership. International Journal of Educational Administration, Management, and Leadership, 63-76.

Permatasari, R. J. (2018). Analisis Pengaruh Pendidikan Dan Pelatihan, Motivasi Dan Kompensasi Terhadap Kinerja Karyawan (Pada Citibank Pondok Indah Jakarta Selatan). JENIUS (Jurnal Ilmiah Manajemen Sumber Daya Manusia), 1(3).

Priansa, Doni Juni, "Perencanaan Dan Pengembangan SDM", CV Alfabeta, Bandung, 2018.

Rawi, R. D. P., \& Halina, N. (2019). Analisis Pengembangan Karir Yang Efisien Pada Badan Kepegawaian Dan
Pengembangan Sumber Daya Manusia (BKPSDM) Kota Sorong.

Robin Dan Coutler, "Manajemen Sumber Daya Manusia", Salemba Empat, Jakarta, 2014.

Salim, A. O., \& Rawi, R. D. P. (2020). Pengaruh Jaminan Sosial Tenaga Kerja Terhadap Produktivitas Kerja Karyawan Pada PT Sumber Abadi Indonesia Cabang Kota Sorong Papua Barat. Jurnal Ilmiah Manajemen Emor (Ekonomi Manajemen Orientasi Riset), 4(1), 32-40.

Simamora, Henry, "Manajemen Sumber Daya Manusia", CetakanPertama Edisi Ketiga, Yogyakarta, Penerbit:Ykpn, 2014.

Sinambela, Lijan Poltak dan sinambela Sarton, "Manajemen Kinerja", Raja Grafindo Persada, Jakarta, 2019

Sugiyono, "Metode Penelitian Pendidikan Pendekatan Kuantitatif, Kualitatif dan

Sunarsi, D., Akbar, I. R., Rozi, A., Khoiri, A., \& Salam, R. (2021, January). The Influence of Motivation and Work Discipline on Employee Performance at the Yogyakarta Tourism Service. In Proceeding The First International Conference on Government Education Management and Tourism (Vol. 1, No. 1, pp. 1-7).

Sunarsi, D., Wijoyo, H., Prasada, D., \& Andi, D. (2020, September). Pengaruh lingkungan kerja terhadap kinerja karyawan pada pt. Mentari persada di jakarta. In Seminar Nasional Manajemen, Ekonomi, Akuntansi (Vol. 5, No. 1, pp. 117-123).

Sunyoto, Danang." Manajemen Sumber Daya Manusia",CAPS.Yogyakarta, 2013.

Sutrisno, Edy, "Manajemen Sumber Daya Manusia", Edisi Pertama Cetakan kesembilan, Kencana, Jakrta, 2017.

Wilandari, D. F., Sunarsi, D., \& Mas'adi, M. (2021). Pengaruh Penilaian Kerja Terhadap Kinerja Karyawan Pada PT. Jaya Mandiri Rekabuana di Cilandak. Jurnal Ekonomi Efektif, 3(2). 